\title{
Materi Sejarah Masa Hindu-Buddha dan Penggunaan Sumber Belajar Sejarah dalam Pembelajarannya di SMK
}

\author{
Nofiyah Mardiani, Umasih, Murni Winarsih \\ Program Pascasarjana, Universitas Negeri Jakarta \\ nofiyahmardiani_ps17s2@mahsiswa.unj.ac.id, umasih@unj.ac.id,winarsih.murni@yahoo.com \\ Universitas Negeri Jakarta
}

\begin{abstract}
Learning in Vocational Schools is learning aimed at improving intelligence, knowledge, personality, noble character, and the skills of students to live independently and to take further education in accordance with their vocational programs. learning resources used in vocational schools are expected to be very varied for this independence. learning resources can be physical and non physical. Types of learning resources include, messages (in the form of learning materials, folklore, fairy tales, advice, Islamic saga, story stories), people (learners), materials (transparency, films, slides, book tapes, pictures), equipment (ohp , tv, camera, blackboard), methods (lectures, discussions, simulations, independent learning), environment (rooms, studios, halls, prayer rooms, mosques). In history learning, these learning resources can be used. During the HinduBuddhist development, historical learning could use heritage buildings. Looking at the latest curriculum, that learning activities should force the student center to create creativity in learning. This study used qualitative methods for three schools using interview instruments to Indonesian history teachers and students as samples and documented studies about learning activities. The results found that the lack of creativity for teachers to utilize technology, especially the internet, one of which is to use films, documentaries or videos, and visit local cultural heritage sites and museums as media and sources of historical learning. So that it causes history learning to be delivered monotonously. The purpose of this study looks at the use of historical learning resources in Vocational Schools and the impact of the use of these learning resources. Until finally the purpose of this study is to provide solutions for ways of innovation and creation in history learning in vocational schools so that they are in accordance with their vocational training.
\end{abstract}

Keywords: Keywords: Vocational High School (SMK), historical learning resources, history learning material on Hindu-Buddhist and Islamic development.

\section{A. Pendahuluan}

Manusia adalah makhluk hidup yang sangat menakjubkan. Pelbagai keajaiban yang ada di dalam tubuh manusia menunjukkan bahwa makhluk ini diciptakan penuh dengan ketelitian dan kecermatan. Tubuh manusia yang sangat luar biasa itu dibekali dengan instrumen yang lengkap dan canggih, yang memungkinan manusia untuk dapat melakukan pengembangan, baik itu yang ada di dalam dirinya sendiri maupun di lingkungan tempat tinggalnya di dunia ini. Meski demikian, segala kelengkapan yang ada dalam tubuh manusia tidak dapat dikatakan sempurna jika tidak dikembangkan secara optimal. Pada hakikatnya, segala instrumen yang melekat dalam diri manusia hanyalah sebuah alat yang apabila tidak dipergunakan dengan baik tidak akan memiliki daya guna bagi pemiliknya. Dia akan berguna jika dapat dimanfaatkan secara optimal sesuai dengan fungsinya. Kecanggihan pelbagai macam instrumen yang dibekalkan dalam tubuh manusia menuntunnya bisa belajar dan mengembangkan dirinya. Instrumen-instrumen itu berfungsi untuk menangkap, mengolah, 
dan menanggapi informasi, serta instrumen untuk memberi respons terhadap hasil pengolahan serta penanggapan terhadap informasi tersebut. ${ }^{1}$

Dalam konteks mikro, pembelajaran merupakan suatu kegiatan yang dilakukan oleh guru dalam menyampaikan materi yang diajarkan kepada siswa dalam suatu lembaga pendidikan. Perubahan peserta didik menuju perubahan yang baik terdapat pada proses pembelajaran. Pada proses pembelajaran di sekolah, belajar merupakan sebuah proses yang terjadi pada manusia dengan berpikir, merasa, dan bergerak untuk memahami setiap kenyataan yang diinginkannya untuk menghasilkan sebuah perilaku, pengetahuan, atau teknologi atau apapun yang berupa karya dan karsa manusia tersebut. Pembelajaran merupakan bantuan yang diberikan pendidik agar dapat terjadi proses perolehan ilmu dan pengetahuan, penguasaan kemahiran dan tabiat, serta pembentukan sikap dan kepercayaan peserta didik. Atau dengan kata lain pembelajaran adalah suatu proses untuk membantu peserta didik agar dapat belajar dengan baik. Komponen dalam pembelajaran salah satunya adalah sumber belajar. $^{2}$

Sumber belajar dalam arti sempit adalah semua sarana pembelajaran yang dapat menyajikan pesan secara auditif maupun visual saja, misalnya OHP, slides, video, film, dan perangkat keras lainnya. ${ }^{3}$ Sedangkan Edgar Dale (2003) menyatakan bahwa sumber belajar adalah pengalaman yang dimiliki. ${ }^{4} \mathrm{Hal}$ ini mempunyai makna proses perubahan tingkah laku ke arah yang lebih sempurna sesuai dengan tujuan yang diharapkannya sebagai sumber belajar, sepanjang hal itu membawa pengalaman yang menyebabkan belajar. Sumber belajar (resources) pada dasarnya dipakai dalam pendidikan atau latihan sebagai suatu system yang terdiri dari sekumpulan bahan atau situasi yang diciptakan dengan sengaja dan dibuat agar memungkinkan peserta didik belajar secara individual. Penggunaan sumber belajar terdapat pada setiap jenjang sekolah, mulai dari sekolah dasar hingga sekolah menengah. Salah satu mata pelajaran yang menggunakan sumber belajar adalah mata pelajaran sejarah.

Sumber belajar sejarah dapat berupa tulisan (tulisan tangan atau hasil cetak), gambar, foto, narasumber, benda-benda alamiah dan benda-benda hasil budaya. Sumber belajar sejarah pada pembahasan di sekolah umumnya berkaitan dengan dimulainya zaman pra-

\footnotetext{
1 Arlina Gunarya, "Model Perilaku Belajar", dalam TOT Basic Study Skills, (Agustus 2011), hal. 3.

2 Arie Dwita Merdiana, Hamdan Tri Atmaja, Andy Suryadi, "Pecinan Semarang Sebagai Sumber Belajar Sejarah Pokok Bahasan Kolonialisme Kelas XI IPS Di SMA Nasional Nusaputera Semarang Tahun Pelajaran 2016/2017”, Indonesian Journal of History Education, Vol .5, No. 1 (2017).

${ }^{3}$ Nana Sudjana \& Ahmad Rifai, Sumber Belajar dan Alat Pelajaran, (Jakarta: Bumi Aksara, 2003), hal. 76.

${ }^{4}$ Nana Sudjana \& Ahmad Rifai, Sumber Belajar...., hal. 76.
} 
aksara hingga zaman saat ini. Satu pembahasan dalam mata pelajaran sejarah adalah perkembangan Hindu-Budha dan Islam. Sumber belajar sejarah pada pembahasan tersebut mencakup banyak hal diantaranya proses kedatangan hingga pengaruhnya di Indonesia. Perkembangan Hindu-Budha dan Islam sudah dikenal pada sekolah tingkat dasar sampai menengah, yang bergantung dengan konteks KI dan KD yang diterapkan pada jenjang sekolah tersebut. Sekolah Menengah Kejuruan (SMK) merupakan salah satu jenjang yang mempelajari perkembangan Hindu-Budha dan Islam di Indonesia. Pada materi Sejarah Indonesia, Perkembangan Hindu-Budha dan Islam masuk pada KD 3.5 dan 3.6. SMK merupakan sekolah dengan menggunakan sumber belajar yang beragam. Hal ini dikarenakan sebagian mata pelajaran merupakan mata pelajaran yang produktif. Pelajaran produktif di SMK menyebabkan setiap pembelajaran menghasilkan sebuah karya atau produk. Pada pelajaran produktif tersebut menyebabkan lingkungan SMK selalu berkaitan dengan kegiatan praktek. Teori dijelaskan dalam porsi yang jauh lebih sedikit dan singkat. Dengan begitu, apapun yang menjadi tempat praktek menjadi sumber belajar.

Menurut pengalaman peneliti tentang penggunaan sumber belajar sejarah di SMK untuk materi perkembangan Hindu-Budha dan Islam, sumber hanya berpaku pada buku teks yang disediakan sekolah. Secara umum, tenaga pendidik tidak menggunakan sumber belajar dengan baik dan juga tidak variatif. Sebagian besar pelajaran di SMK berupa kegiatan produktif (menghasilkan karya), meskipun hal itu hanya untuk mata pelajaran sesuai dengan jurusannya. Pada mata pelajaran non-produktif, materi setiap pelajaran hanya menjadi materi tuntas. Sumber belajar sejarah dengan pemanfaatan media teknologi pun, sering ditemui hanya berupa tampilan gambar-gambar dengan penjelasan singkat. Banyak materi pelajaran sejarah di kejuruan hanya menceritakan peristiwa penting-penting meskipun disampaikan dengan cara yang menyenangkan. Secara umum, penggunaan sumber belajar yang dipakai para guru diambil dari sumber sejarah yang sudah ada pada media internet, yang dalam hal ini materinya banyak ditemukan pada aplikasi google.

Dari beberapa wawancara singkat kepada peserta didik tentang pembelajaran sejarah, diketahui bahwa mayoritas dari mereka sering diminta guru untuk menyalin tulisan di buku ke atas papan tulis. Pada sekolah dengan fasilitas yang memadai, mereka bisa menggunakan media teknologi sebagai sumber belajar seperti halnya slide power point. Namun penggunaan sumber belajar tersebut dirasa membosankan, sebab hanya disertai uraian satu arah pengajarnya saja. Sebagian peserta didik yang ditemui peneliti mengatakan sebenarnya sejarah tidak sesulit matematika dan IPA, namuan karena pengunaan sumber belajar yang 
sama di setiap materinya membuat minat peserta didik menengah kejuruan sangatlah kurang. Rendahnya minat sejarah tersebut mengakibatkan minimnya produktivitas pembelajaran sejarah. Dalam kegiatan pembelajaran, guru hanya mengajar dengan bercerita yang diuraikan secara berulang, membuat siswa menjadi merasa bosan. Kegiatan yang kurang produktif itu membuat peserta didik teralihkan perhatiannya dan melakukan hal yang tidak baik, seperti tidak memperhatikan guru, mengobrol di luar topik pembelajaran dengan temannya, bahkan beberapa di antaranya ditemukan tengah tertidur dalam kelas.

Pada perkembangan IPTEK ini, pendidikan sejarah bisa menggunakan teknologi untuk kegiatan pembelajaran sebagai sumber belajar. Pendidikan sejarah merupakan media pendidikan yang paling baik untuk memperkenalkan kepada peserta didik tentang bangsanya di masa lampau. Melalui sumber sejarah dari kemajuan IPTEK, SMK merupakan jenjang yang diharapkan menghasilkan kegiatan dengan sebuah karya, seperti pemanfaatan situs budaya yang ditampilkan dengan kunjungan dan dibuat video sehingga bisa dilihat oleh umum serta kreatifitas dalam pembuatan tugas seperti pembuatan candi 4 dimensi dan lain sebagainya. Mata pelajaran sejarah seharusnya tidak hanya terpaku pada buku-buku pelajaran. Harus ada inisiatif dari guru untuk mencari sumber belajar dari materi-materi lain yang dapat mendukung keberlangsungan pembelajaran sejarah yang efektif dan keatif.

Berdasarkan masalah yang dihadapi serta kondisi lapangan mengenai pembelajaran sejarah, peneliti ingin melihat bagaimana pemanfaatan sumber-sumber belajar yang digunakan serta mencari solusi agar pembelajaaran sejarah tidak membosankan bagi peserta didik. Penelitian ini dilakukan untuk mengetahui masalah yang dihadapi dalam pelaksanaan kegiatan belajar mengajar sesuai kurikulum terbaru pada mata pelajaran sejarah dengan menggunakan sumber-sumber belajar yang berkaitan dengan materi. Latar belakang tersebut membuat peneliti melakukan kajian dengan judul, "Materi Sejarah Masa Hindu-Buddha dan Penggunaan Sumber Belajar Sejarah dalam Pembelajarannya di SMK.”

\section{B. Hakikat Materi Pembelajaran dan Sumber Belajar Sejarah}

\section{Pengertian Pembelajaran}

Pembelajaran merupakan kegiatan antara guru dan peserta didik yang menghasilkan kreatifitas berfikir untuk mengkonstruksi pengetahuan baru sehingga tercipta penguasaan materi pelajaran dengan baik. Secara etimologis, pembelajaran berasal dari kata "belajar" yang mendapat awalan (pem-) dan akhiran (an). Sedangkan dalam Bahasa Yunani, pembelajaran disebut dengan "instructus" yang artinya 
menyampaikan pikiran. Pada dasarnya, pembelajaran adalah proses interaksi yang terjalin di antara guru dengan peserta didik, dan juga lingkungan yang ada disekitarnya. Dalam proses tersebut, terdapat upaya untuk meningkatkan kualitas dari peserta didik agar menjadi lebih baik dari sebelumnya. Menurut UU Pendidikan Nasional No 20 Tahun 2003, pembelajaran adalah proses interaksi peserta didik dengan pendidik dan sumber belajar dan lingkungan belajar. Dengan demikian, pembelajaran merupakan proses belajar yang dibangun oleh guru untuk mengembangkan dan meningkatkan kreatifitas siswa, serta dapat meningkatkan kemampuan mengkonstruksi pengetahuan baru sebagai upaya meningkatkan penguasaan materi pelajaran.

\section{Pembelajaran Sejarah}

Pembelajaran sejarah merupakan pendidikan yang berkaitan dengan sejarah atau peristiswa masa lampau. Pembelajaran sejarah diberikan dengan tujuan agar siswa dapat memiliki sikap yang berorientasi pada perspektif kritis logis dengan pendekatan historiologis. ${ }^{5}$ Hal itu dikarenakan pembelajaran sejarah mengkaji perkembangan masyarakat dari masa lampau hingga masa kini. Pembelajaran sejarah di sekolah merupakan salah satu pelajaran untuk mencapai tujuan pendidikan nasional, sekaligus sebagai upaya untuk menumbuhkan dan mengembangkan rasa tanggung jawab kemasyarakatan dan kebangsaan peserta didik dalam mengantisipasi perubahan dan menghadapi tuntutan pertumbuhan zaman. Pendidikan dan pembelajaran sejarah tampaknya menjadi perhatian banyak orang karena terdapat banyak kesan yang kurang baik di dalam pelaksanaannya. Baik di Amerika Serikat ataupun negaranegara lainnya, outcomes pembelajaran sejarah di tengah peserta didik seolah menjadi sumber ketidakpuasan. Keluhan bahwa, "anak-anak tidak mengetahui sejarah," telah menjadi ungkapan yang selalui dipikirkan oleh para pendidik sejarah, bahkan telah masyhur sejak awal tahun 1900-an. ${ }^{6}$

Jika pembelajaran merupakan suatu sistem yang memiliki tujuan untuk membantu proses belajar siswa, dengan isi serangkaian peristiwa yang secara sengaja dirancang

\footnotetext{
${ }^{5}$ Y.R. Subakti, "Paradigma Pembelajaran Sejarah Berbasis Konstruktivisme", Jurnal SPPS, Vol. 24, No. 1, (April 2010).

${ }^{6}$ Sam Wineburg, Historical Thinking and Other Unnatural Acts: Charting the Future of Teaching the Past, (Temple University Press, 2001), hal. viii.
} 
untuk mempengaruhi secara internal terjadinya proses belajar, ${ }^{7}$ maka pembelajaran sejarah lebih mengarah pada masalah internalisasi nilai-nilai pengetahuan dan keterampilan yang berkaitan dengan sejarah. Dengan demikian, maka kita dapat memahami pembelajaran sejarah sebagai pendidikan dalam suatu masyarakat (bangsa) yang bertujuan untuk menangkap prinsip-prinsip (nilai-nilai) yang berlaku dalam suatu masyarakat dengan konteks waktu yang berkaitan dengan masa sekarang.

\section{Pembelajaran Sejarah Materi Perkembangan Hindu-Budha}

A) Teori masuknya Agama dan Kebudayaan Hindu dan Buddha di Indonesia

Teori masuknya Hindu Budha ke Indonesia yang dikemukakan para ahli sejarah umumnya terbagi menjadi 2 pendapat. Pendapat pertama menyebutkan bahwa dalam proses masuknya kedua agama ini, bangsa Indonesia hanya berperan pasif. Bangsa Indonesia dianggap hanya sekedar menerima budaya dan agama dari India. Ada 3 teori yang menyokong pendapat ini yaitu teori Brahmana, teori Waisya, dan teori Ksatria. Pendapat kedua menyebutkan bahwa banga Indonesia juga bersifat aktif dalam proses penerimaan agama dan kebudayaan Hindu Budha. Dua teori yang menyokong pendapat ini adalah teori arus balik dan teori Sudra.

1) Teori Brahmana oleh J.C. van Leur

Teori Brahmana adalah teori yang menyatakan bahwa masuknya Hindu Budha ke Indonesia dibawa oleh para Brahmana (golongan pemuka agama) di India. Dasar teori ini adalah prasasti-prasasti peninggalan kerajaan Hindu Budha di Indonesia, yang mayoritas menggunakan huruf Pallawa \& Bahasa Sanskerta.

2) Teori Waisya oleh NJ. Krom

Teori Waisya menyatakan bahwa terjadinya penyebaran agama Hindu Budha di Indonesia adalah berkat peran serta golongan Waisya (pedagang) yang merupakan golongan terbesar masyarakat India yang berinteraksi dengan masyarakat Nusantara. Dalam teori ini, para pedagang India dianggap telah memperkenalkan kebudayaan Hindu dan Budha pada masyarakat lokal ketika mereka melakukan aktivitas perdagangan.

3) Teori Ksatria oleh C.C. Berg, Mookerji, dan J.L. Moens

7 R.M. Gagne \& L.J. Briggs, Principle of Instructional Design (2nd ed.), (New Yorks: Holt, Rinehart, and Winston, 1979), hal. 3. 
Menurut teori ini, penyebaran agama dan kebudayaan Hindu-Budha di Indonesia dilakukan oleh golongan ksatria. Dalam teori ini, sejarah penyebaran Hindu Budha di kepulauan Nusantara tidak bisa dilepaskan dari sejarah kebudayaan India pada periode yang sama. Seperti diketahui bahwa di awal abad ke 2 Masehi, kerajaan-kerajaan di India mengalami keruntuhan karena perebutan kekuasaan. Penguasa kerajaan-kerajaan yang kalah perang pada masa itu diidentifikasi telah melarikan diri ke Nusantara.

4) Teori Arus Balik oleh F.D.K Bosch

Teori ini menjelaskan bahwa penyebaran Hindu Budha di Indonesia terjadi karena peran aktif masyarakat Indonesia di masa silam. Menurut Bosch, pengenalan Hindu Budha pertama kali memang dibawa oleh orang-orang India kepada orang Indonesia, yang kemudian orang-orang tersebut tertarik untuk mempelajari kedua agama ini secara langsung dari negeri asalnya, India. Mereka berangkat dan menimba ilmu di sana dan ketika kembali mereka kemudian mengajarkan apa yang diperolehnya pada masyarakat.

5) Teori Sudra oleh van Faber

Dalam teori ini, penyebaran agama dan kebudayaan Hindu Budha di Indonesia diawali oleh para kaum Sudra atau budak yang bermigrasi ke wilayah Nusantara. Mereka menetap dan menyebarkan ajaran agama mereka pada masyarakat pribumi hingga terjadilah perkembangan yang signifikan terhadap arah kepercayaan mereka yang awalnya animisme dan dinamisme menjadi percaya pada ajaran Hindu dan Budha.

Menurut sebagian sejarahwan, proses masuknya Hindu-Budha ke Indonesia merupakan bagian yang kontroversial karena tidak ditemukannya secara pasti bukti kedatangan agama tersebut. Menurut bukti-bukti sejarah, Islam telah ditemukan berkembang begitu saja di Indonesia. Oleh sebab itu, Teori-teori kedatangan HinduBudha banyak yang tidak dijelaskan secara detail oleh guru kepada peserta didik.

B) Pengaruh Hindu Buddha di Indonesia

Perkembangan Agama Hindu dan Budha yang terjadi sejak awal abad ke-2 Masehi, telah berpengaruh terhadap beberapa aspek kehidupan masyarakat Nusantara pada masa itu. Pengaruh tersebut bahkan masih dapat dilihat dan dirasakan hingga saat ini, baik itu pengaruh yang mutlak berasal dari ajaran dan kebudayaan Hindu- 
Budha ataupun pengaruh yang berasal dari akulturasi budaya India dengan budaya lokal di masa itu. Pengaruh itu terjadi dalam sejumlah bidang, di antaranya:

1) Bidang Agama

Semula masyarakat Indonesia menganut kepercayaan animisme dan dinamisme, namun karena masuknya ajaran Hindu dan Budha yang dibawa oleh para pedagang dan pendeta, kepercayaan animisme dan dinamisme yang dianut oleh masyarakat Nusantara tempo dulu kemudian melebur dan berakulturasi dengan ajaran agama Hindu-Budha. Kebudayaan baru dalam hal beragama yang berasal dari akulturasi ini contohnya adalah upacara pemujaan, tata krama tertentu, dan bentuk tempat peribatan.

2) Bidang Politik dan Pemerintahan

Sistem politik dan pemerintahan yang diperkenalkan oleh orang-orang India dan membuat masyarakat yang awalnya hidup dalam kelompok-kelompok kecil menjadi bersatu dan membentuk sebuah kekuasaan yang lebih besar dengan pemimpin tunggal yang berupa seorang raja. Karena pengaruh inilah, beberapa kerajaan Hindu Budha seperti Kerajaan Sriwijaya, Majapahit, Tarumanegara, dan Kutai, bisa muncul di Nusantara.

3) Bidang Arsitektur

Tradisi megalitikum peninggalan nenek moyang bangsa Indonesia yang berupa punden berundak juga diyakini telah berakulturasi dengan ilmu arsitektur yang berasal dari India karena terdapat perpaduan dalam gaya arsitektur pembangunan candi di Nusantara. Contohnya bisa dilihat dari arsitektur Candi Borobudur yang berbentuk limas dan berundak-undak.

4) Bidang Bahasa dan Aksara

Huruf Pallawa dan Bahasa Sanskerta yang ada dalam sejumlah prasasti kerajaan-kerajaan Nusantara menunjukkan bahwa pengaruh budaya India di Indonesia juga bersinggungan dengan aspek bahasa dan aksara. Selanjutnya penggunaan Aksara Pallawa tidak populer lagi, namun penggunaan Bahasa Sanskerta justru berlanjut dengan sangat pesat. Ini dibuktikan dengan adanya beberapa kata atau frase Bahasa Indonesia yang sebetulnya berasal dari bahasa itu, misalnya Pancasila, Kartika Eka Paksi, Parasamya Purnakarya Nugraha, dan lain sebagainya.

5) Bidang Sastra 
Dalam bidang ini, pengaruh Hindu Budha di Indonesia tampak dalam karya sastra yang dikenal di Indonesia seperti Kitab Ramayana dan Mahabarata yang telah memperkaya khasanah epos dalam pewayangan Indonesia. Adanya kedua kitab itu juga memacu beberapa pujangga Nusantara untuk menghasilkan karyanya sendiri, seperti Empu Dharmaja dari kerajaan Kediri yang menyusun Kitab Smaradhahana, Empu Sedah dan Empu Panuluh dari kerajaan Kediri yang menelurkan karya Kitab Bharatayuda, Empu Tanakung yang membuat Kirab Lubdaka, Empu Kanwa yang memiliki karya Kitab Arjunawiwaha, Empu Triguna dengan Kitab Kresnayana-nya, Empu Panuluh yang menulis Kitab Gatotkacasraya, Empu Tantular yang membuat Kitab Kitab Sotasoma, dan Empu Prapanca yang masyhur dengan magnum opusnya yang berjudul Kitab Negarakertagama.

\section{Pengertian dan Jenis Sumber Belajar}

Pengertian sumber belajar dapat diartikan secara sempit dan secara luas, sesuai dengan karakteristik khasnya. Secara sempit pengertian itu dimaksudkan pada bahanbahan cetak, sedangkan secara luas adalah daya yang bisa dimanfaatkan guna kepentingan proses belajar mengajar. ${ }^{8}$ Dalam pandangan lain, sumber belajar dapat pula dimaknai sebagai segala sesuatu yang dapat dimanfaatkan oleh siswa untuk mempelajari bahan sesuai dengan tujuan yang hendak dicapai. ${ }^{9}$ Dalam pengelolaan sumber belajar, perlu diperhatikan aspek sumber daya dan lingkungan yang dimiliki sekolah karena keduanya merupakan bagian penting. ${ }^{10}$ Dengan demikian, dapat dipahami bahwa sumber belajar merupakan hal penting yang meliputi pelbagai alat bantu dengan tujuan untuk membangkitkan minat terhadap mata pelajaran tersebut.

Terdapat ragam persepsi mengenai sumber belajar. B.P Sitepu (2014) menguraikan bahwa sumber belajar terdiri dari pesan; orang; bahan; peralatan; metode; dan lingkungan. Jenis-jenis sumber belajar tersebut dapat dimanfaatkan untuk pengembangan materi sejarah. Terkait dengan materi perkembangan Hindu-Budha dan Islam, jenis sumber belajar tidak hanya berupa pesan, bahan, dan motode, namun

\footnotetext{
8 Suratno, Macam-Macam Sumber Belajar, (Jakarta: Gramedia Pustaka Utama, 2008).

9 W. Sanjaya, Strategi Pembelajaran: Berorientasi Standar Proses Pendidikan, (Jakarta: Kencana Prenada Media Group, 2006), hal. 174.

10 Martinis Yamin, Strategi dan Metode dalam Model Inovasi Pembelajaran, (Jakarta: Gaung Persada Press Group, 2013), hal. 99.
} 
juga bisa memanfaatkan lingkungan yang berupa tempat ibadah dari agama tersebut. Sedangkan secara umum, sumber belajar dapat dikategorikan pula sebagai: (a) sumber belajar yang dirancang (learning resources by design), dan (b) sumber belajar yang dimanfaatkan (learning resources by utilization).

Berbagai jenis sumber belajar tersebut, pada dasarnya tidak boleh dilihat secara sebagian, namun mesti dilihat sebagai sebuah kesatuan utuh demi tercapainya pembelajaran yang lebih baik dan berdampak positif terhadap hasil pembelajaran. Bagaimanapun, sumber belajar itu adalah hal yang berdampak karena didesain agar memiliki fungsi atau manfaat seperti halnya peningkat produktivitas pembelajaran; pemberi kemungkinan atas pembelajaran individual; pemberi dasar yang lebih ilmiah terhadap pembelajaran; dan lain sebagainya. Dengan begitu, kita dapat memahami bahwa sumber belajar merupakan suatu sarana/alat belajar baik di sekolah maupun di luar sekolah yang dapat digunakan untuk mendukung dan memudahkan kegiatan pembelajaran sehingga mempermudah dalam pencapaian tujuan pembelajaran.

\section{Sumber Belajar Sejarah}

Sumber pembelajaran sejarah dapat dimaknai sebagai suatu sarana pembelajaran dan pengajaran yang memiliki kaitan dengan ilmu sejarah yang digunakan dengan peran sebagai acuan pelaksanaan dalam kegiatan pembelajaran. ${ }^{11}$ Dengan adanya sumber pembelajaran sejarah, maka kegiatan belajar serta mengajar akan sangat terbantu karena penyampaian materi ajar kepada peserta didik dapat dilakukan dengan dasar atau landasan yang jelas. Sebenarnya, sumber belajar dapat diperoleh dari pelbagai macam tempat yang erat kaitannya dengan kajian sejarah. Hal itu membuat sumber sejarah sebenarnya tidak terlalu sulit untuk dicari. Secara garis besar, sumber belajar dikelompokkan menjadi lima kategori, yakni manusia, buku/perpustakaan, media masa, alam lingkungan, dan media pendidikan. Namun demikian kita mesti memahami pendekatan pembelajaran dengan baik karena tidak semua metode, model, dan media pembelajaran cocok digunakan dalam mata pelajaran sejarah.

Dengan demikian, kita dapat pahami bersama bahwa kategori-kategori yang ada dalam sumber pembelajaran sejarah tersebut bisa digunakan dalam pelajaran sejarah,

11 Trisna Sri Wardani Soebijantoro, "Upacara Adat Mantu Kucing di Desa Purworejo Kabupaten Pacitan (Makna Simbolis dan Potensinya Sebagai Sumber Pembelajaran Sejarah)", Jurnal Agastya, Vol. 7, No. 1 (Januari, 2017), hal. 70. 
namun harus tetap sesuai dengan materi yang tengah dibahas. Materi-materi tersebut mesti dibuat dengan perencanaan pembelajaran yang bisa memuat strategi, metode, model, atau media yang akan digunakan. Seluruh rangkaian rencana pembelajaran yang demikian, akan menghasilkan proses pembelajaran yang akan berlangsung.

\section{Pembahasan Hasil Penelitian}

\section{Penggunaan Sumber Belajar Sejarah}

Sumber belajar merupakan alat atau sarana yang digunakan pada saat pembelajaran. Dalam uraiannya, Nana sudjana dan Ahmad Rivai menjelaskan bahwa sumber belajar sejarah terdiri dari pesan, manusia, bahan, teknik dan lingkungan. ${ }^{12}$ Sumber belajar yang demikian digunakan dari tingkat sekolah dasar hingga menengah untuk setiap mata pelajaran. Mata pelajaran yang juga mengharuskan menggunakan sumber belajar adalah pelajaran sejarah. Sebagaimana dibahas sebelumnya, sumber belajar sejarah bisa didapat dari mana saja dan kapan saja, asalkan sumber tersebut berkaitan dengan materi atau kajian sejarah. Bentuknya bervariasi mulai dari buku, bangunan bersejarah, hingga ke lingkungan sekolah. Namun meskipun begitu, dewasa ini kita dapat melihat bahwa pembelajaran sejarah banyak yang hanya menggunakan satu sumber saja, yakni buku cetak. Kurikulum 2013 pun seolah mengaminkan hal itu karena hanya menggunakan satu sumber saja selama satu tahun kegiatan pembelajaran. Siswa berinisial ZA dari kelas X, SMKN 42 Jakarta menyebutkan bahwa, "Pada mata pelajaran sejarah terkadang bersumber dari buku beberapa mengambil informasi di google dan dirangkum menjadi satu di media Power Point" (Catatan Wawancara Peserta Didik, selanjutnya disingkat CWPD, No. 7). Hal serupa disampaikan pula oleh ARD kelas X SMK Insan Cita, bahwa mereka belajar dengan "sumber belajarnya dari buku yang dipakai setiap hari dan media PPt" (CWPD, 8). Senada AB dari kelas X SMKN 42 Jakarta menguraikan, "Pelajaran sejarah hanya memakai aplikasi google dan buku paket" (CWPD, 9). SR dari kelas X SMK Insan Cita seolah ingin menguatkan karena menurutnya sumber belajar, "hanya memakai buku LKS saja, Bu"(CWPD, 10).

Berdasarkan jawaban peserta didik tersebut, kita ketahui bahwa sumber belajar yang digunakan masih kurang. Padahal sumber belajar tidak melulu dengan sumber

12 Nana Sudjana dan Ahmad Rivai, Teknologi Pengajaran, (Bandung: Sinar Baru Algensindo, 2007), hal. 7980 . 
buku saja, masih banyak sumber-sumber lain untuk menunjang kegiatan pembelajaran. Contohnya, media film dokumenter bisa dipakai sebagai sumber belajar yang cukup efektif untuk meningkatkan minat belajar siswa terhadap mata pelajaran sejarah. ${ }^{13}$ Mungkin kendalanya cuma satu, yakni kurangnya jam mengajar sebab film durasinya cukup lama.

Menurut penelitian yang dilakukan, penggunaan sumber belajar sejarah memiliki dampak, dalam beberapa hal berikut:

a) Pembelajaran Sejarah

Pembelajaran sejarah merupakan pembelajaran yang membahas peristiwa zaman masa lalu hingga masa sekarang ini. Namun banyak peserta didik yang tidak menyukai pelajaran sejarah dikarenakan banyak hal. SSM dari kelas X SMKN 42 Jakarta mengatakan alasan ketidaksukaannya, "Menurut saya belajar sejarah membosankan, karena saya tidak suka menghapal dan sangat membebankan, harus ekstra belajar" (CWPD, No. 1). AF dari kelas X SMKN 42 juga menambahkan, "Menurut saya sih pelajaran sejarah membosankan, karena terlalu banyak materi dan penyampaiannya terlalu monoton sehingga siswa menjadi jenuh" (CWPD, No. 2). BNA kelas X SMKN 42 juga berpendapat, bahwa "Menurut saya pelajaran sejarah sedikit membosankan karena kalau sedang mengerjakan tugas selalu panjang jawabannya dan itu agak sedikit membosankan" (CWPD, No. 3). Sementara itu, IAA kelas X SMK Insan Cita mengungkapkan, "Menurut saya pelajaran sejarah baik sih tetapi terlalu sedikit jamnya sehingga kurang efektif" (CWPD, No. 4).

Melihat beberapa pendapat peserta didik tersebut, diketahui bahwa pembelajaran sejarah masih kurang diminati karena pembelajarannya membosankan dan hanya langsung pemberian tugas-tugas saja. Padahal sejatinya tidak demikian sebab tujuan dari pembelajaran sejarah tidak hanya tuntas dalam materi dan pendapatan nilai, namun ada tujuan-tujuan lain yang harus dicapai oleh guru dan peserta didik. Menurut Suryani dan Agung, tujuan pembelajaran sejarah adalah menanamkan semangat cinta tanah air, mengetahui proses terbentuknya negara Indonesia, meningkatkan rasa persatuan dan kesatuan bagi peserta didik, dan mengetahui proses peradaban

13 Lihat lebih lanjut, Mohammad Namiraz Prananda, Sarkadi, dan Nurzengky Ibrahim, "Efektivitas Sumber Pembelajaran Sejarah,” Jurnal Pendidikan Sejarah, Vol. 7, No. 2 (Juli, 2018). 
manusia Indonesia khususnya dan masyarakat dunia pada umumnya darimasa dulu hingga sekarang. ${ }^{14}$

b) Metode Pembelajaran

Dalam proses mengajar, seorang pendidik tidak harus terpaku dengan menggunakan satu metode mengajar, akan tetapi harus menggunakan beberapa metode mengajar yang digunakan secara bervariasi agar pengajaran tidak membosankan. Dalam hal ini, dituntut pula kompetensi guru dalam pemilihan metode pengajaran yang tepat. Oleh karena itu pemilihan dan penggunaan metode yang bervariasi tidak selamanya menguntungkan, bila saja guru mengabaikan faktor-faktor yang mempengaruhi penggunaannya. Menurut M. Sobri Sutikno, Metode pembelajaran adalah cara-cara menyajikan materi pelajaran yang dilakukan oleh pendidik agar terjadi proses pembelajaran pada diri siswa dalam upaya untuk mencapai tujuan. ${ }^{15}$

Metode pembelajaran yang kreatif tidak dilakukan oleh semua guru bidang studi, termasuk dalam pelajaran sejarah Indonesia. Pada tingkat SMK, metode pembelajaran sejarah biasnya dilakukan hanya ceramah dengan student center dan tidak adanya interaksi yang terlaksana dengan baik seperti yang diungkapkan oleh ZA kelas X SMK 42, katanya "Metodenya persentasi saja, itupun murid yang persentasi dan kurang memahami, namun guru kurang menjelaskan" (CWPD, No. 7). AF kelas X SMKN 42 Jakarta juga mengungkapkan, "metodenya cuma ceramah dan diskusi secara langsung" (CWPD, No. 2). AKD kelas X SMK Insan Cita yang notabene lain sekolah, menyatakan hal yang sama, metodenya hanya "ceramah aja" (CWPD, No. 8). BNA dari kelas X SMK Cengkareng 1 juga mengatakan hal yang sama, "metodenya ceramah dan lalu membaca isi buku tersebut" (CWPD, No. 3).

Melihat pada jawaban peserta didik dari tiap-tiap sekolah tersebut, dapat disimpulkan bahwasanya pembelajaran sejarah masih menggunakan metode konvensional yakni ceramah dengan titik pusatnya adalah guru. Guru sejarah masih melakukan pembelajaran dengan model yang sudah sangat lama tanpa pemberharuan. Dampak penggunaan sumber belajar yang digabungkan dengan

\footnotetext{
14 Nunuk Suryani dan Leo Agung, Strategi Belajar Mengajar, (Yogyakarta: Ombak, 2012), hal. 417.

15 M. Sobry Sutikno, Belajar dan Pembelajaran: Upaya Kreatif dalam Mewujudkan Pembelajaran yang Berhasil, (Bandung: Prospect, 2009), hal. 88.
} 
metode pembelajaran yang masih berupa ceramah, menyebabkan tidak terjadi pembelajaran yang aktif dan menyenangkan. Padahal, saat ini pada kurikulum 2013 terbaru menurut metode pembelajaran harus terdiri dari project based learning, problem based learning, inquary learning dan discovery lerning. Melalui metode-metode yang baru bisa membuat pembelajaran sejarah aktif dan menyenangkan.

c) Media yang Digunakan pada Pembelajaran Sejarah

Media merupakan sarana yang dipakai untuk penunjang kegiatan belajar. Berdasarkan arti dari KBBI (Kamus Besar Bahasa Indonesia), media dapat diartikan sebagai perantara, penghubung; alat (sarana) komunikasi seperti koran, majalah, radio, televisi, film, poster, dan spanduk, yang terletak diantara dua pihak (orang, golongan, dan sebagainya). Media pembelajaran merupakan bagian tak terpisahkan dari kegiatan pembelajaran di sekolah. Pemanfaatan media pembelajaran juga merupakan upaya kreatif dan sistematis untuk menciptakan pengalaman yang dapat membantu proses belajar peserta didik. Hal ini dikarenakan media berperan sebagai alat perangsang belajar dan dapat menumbuhkan motivasi belajar sehingga peserta didik tidak mudah bosan dalam mengikuti proses belajar-mengajar.

Pada pelajaran sejarah Indonesia di SMK, media yang digunakan tidak beragam sebagaimana yang disebutkan oleh KBBI. Karena sejarah tidak masuk dalam pelajaran kejuruan, penggunaan media hanya berlandaskan istilah "yang penting peserta didik tuntas" sehingga menyebabkan sejarah hanya menggunakan media itu-itu saja. Seperti yang diungkapkan oleh LHM kelas X SMK Cengkareng 1, katanya "guru sejarah ngejelasinnya ceramah sambil nulis dipapan tulis, itupun sedikit banget" (CWPD, No. 11). KK dari kelas X SMK Insan Cita juga mengungkapkan, "kita hanya dengarkan penjelasan dari guru sambil liat slide power point. Itu juga setiap pembahasan materi” (CWPD, No. 12). Dan sama halnya pula yang disampaikan oleh SDAP kelas X SMKN 42, katanya “(medianya hanya) ceramah, menjelaskan secara keseluruhan dengan PPt" (CWPD, No. 13).

Berdasarkan beberapa jawaban peserta didik, dapat disimpulkan bahwa sejarah hanya menggunakan satu media di setiap sekolah yang diobservasi. Penggunaan sumber dan media yang tidak banyak menyebabkan bahwa 
sejarah masih kurang produktif di SMK. Meskipun menggunakan model student center namun efektivitas pembelajaran masih kurang terjadi.

d) Pemberian Tugas dalam Pembelajaran

Cara guru dalam pemberian tugas merupakan interaksi dalam belajar mengajar. Pemberian tugas yang dilakukan pada guru tergantung dari metode yang diajarkan guru tersebut. Menurut kurikulum 2013 revisi, terdapat empat model pembelajaran, yakni project based learning, problem based learning, dan discovery/inquiry learning. Pada project based learning pemberian tugas berupa proyek dari aktifitas siswa yang berhubungan dengan dunia nyata. Pemberian tugas dengan model project based learning mengutamakan keaktifan peserta didik, dimana keaktifan tersebut menghasilkan keterampilan melalui langkah-langkah pembuatan sehingga dapat menjadi sebuah proyek. Pada pembelajaran sejarah, pemberian tugas ini bisa berupa pembuatan peta konsep, pembuatan candi 4 dimensi, dan sebagainya. Selanjutnya pembelajaran dengan model problem based learning yang merupakan model pembelajaran pemecahan masalah. Model ini merupakan pembelajaran dengan pemahaman tingkat tinggi atau HOTS sehingga peserta didik diharuskan mencari jawaban sendiri dengan masalah yang terkait. Sedangkan untuk discovery learning, merupakan model pembelajaran yang dikembangkan berdasarkan pandangan konstruktivisme dengan penekanan terhadap pengalaman langsung seorang peserta didik dan pentingnya pemahaman terstruktur atau ide-ide penting terhadap suatu disiplin ilmu.

Melihat pada model-model itu, pemberian tugas pada pembelajaran sejarah dapat dilakukan dengan lebih variatif. Namun, sekarang ini guru sejarah hanya menggunakan satu model saja dengan tugas yang diberikan berupa hanya latihan soal-soal. Seperti yang diutarakan oleh IAA kelas X SMK Insan cita: "Pemberian soal-soal dibuku LKS" (CWPD, No. 4). Hal yang sama pula disampaikan oleh Levy Hastana Mitha kelas X SMK Cengkareng 1: "Ngerjain LKS tapi tidak dinilai" (CWPD, No. 10). Namun untuk sekolah SMK 42 Jakarta, pemberian tugas berupa pembuatan makalah dengan diskusi persentasi kelompok. Sebagaimana disampaikan oleh SSM kelas X SMK 42: "Hanya makalah untuk pesentasi PPt" (CWPD, No. 1). Serupa pula yang diutarakan oleh APO kelas X SMK 42: "Makalah, soal bentuk essay dan PG" 
(CWPD, No. 5). Berdasarkan pendapat-pendapat tersebut, bahwa pemberian tugas yang tidak kreatif disebabkan model yang dipakai oleh guru sejarah hanya model pembelajaran masa lampau yakni pembelajaran yang berpusat pada guru sehingga pemberian tugaspun hanya berupa latihan soal dalam bentuk essay dan PG.

e) Kendala yang Dihadapi

Sejarah merupakan mata pelajaran yang membahas peristiwa penting tentang masa lampau dan masa sekarang ini. Dengan kata lain, ketidak-cermatan dalam pemilihan strategi mengajar akan berakibat fatal terhadap pencapaian tujuan pembelajaran yang dilakukan. ${ }^{16}$ Pembelajaran sejarah sudah diajarkan dari sekolah dasar hingga menengah. Pada pembelajaran sejarah tingkat atas, terdapat perbedaan di SMA dan SMK. Perbedaan tersebut menjadi sebuah kendala yang dirasakan oleh guru sejarah tersebut. Salah satunya pendapat dari VL guru sejarah Indonesia di SMK 42 Jakarta yang mengatakan bahwa kendala yang dihadapi mengenai sumber belajar diantaranya buku edisi lama (Catatan Wawancara Guru Sejarah Indonesia, selanjutnya disingkat CWGSI, No. 1). Pendapat guru sejarah lain tentang kendala dalam pembelajaran sejarah mengenai sumber belajar sejarah menurut AA guru sejarah SMK Cengkareng 1 yakni peserta didik yang tidak memiliki buku paket, hanya mempunyai buku LKS yang penjelasan serta pembahasan yang terbatas CWGSI, No. 2). Lalu kendala yang dihadapi pula menurut DS guru sejarah SMK Insan Cita mengatakan bahwa kendala pembelajaran sejarah mengeani sumber belajar yakni tidak mampunya peserta didik membeli buku paket sejarah dan peraturan sekolah yang tidak memperbolehkan peserta didik membawa telepon pintar untuk tambahan sumber belajar (CWGSI, No. 3).

Melihat pendapat para guru sejarah tersebut, diketahui bahwasanya kendala yang dirasakan terkait sumber belajar yakni pelajaran sejarah yang bukan sebagai pelajaran produktif disekolah menyebabkan sumber belajar yang dipakaipun sangat kurang sehingga menyebabkan pembelajaran kurang diminati oleh peserta didik SMK. Berdasarkan hasil penelitian, tidak produktifnya pembelajaran di SMK disebabkan oleh kurangnya sumber belajar

\footnotetext{
${ }^{16}$ I Gede Widja, Dasar-Dasar Pengembangan Strategi Serta Metode Pengajaran Sejarah, (Jakarta: Proyek Pengembangan Lembaga Pendidikan Tenaga Kependidikan, 1989), hal. 13.
} 
yang digunakan serta metode yang digunakan dalam kegiatan pembelajaran. Hal ini serupa dengan pendapat dari M. Sadikin yang menguraikan bahwa kendala-kendala yang dihadapi guru dalam pembelajaran sejarah pada zaman sekarang ini adalah: (1) Minimnya sumber belajar atau referensi yang bisa dijadikan sebagai acuan dalam pembelajaran; (2) Ketidaksesuaian antara study dokumen dan proses pembelajaran sehingga menyebabkan masalah yang sangat signifikan; (3) Keterbatasan dan masih minimnya pengetahuan sejarah secara menyeluruh akibat perbedaan latar belakang pedidikan. ${ }^{17}$

Kendala lain yang dihadapi dalam pembelajaran sejarah yakni berupa ketidaksesuaian guru sejarah dengan pendidikan yang ditempuhnya. Pada penelitian ini, tiga sekolah sudah sesuai dengan peraturan yakni guru bidang study harus sesuai dengan pendidikan yang linear. Pada penelitian ini ditemukan satu guru pendamping tidak sesuai dengan pendidikan linear. Yakni guru sejarah Indonesia untuk program AP dan AK pada SMK Cengkareng 1 yang ternyata seorang guru alumni pendidikan ekonomi. Berdasarkan hasil wawancara singkat, yang bersangkutan mengajar sejarah karena guru sejarah Indonesia hanya satu orang dan sudah mengajar di SMA dalam satu yayasan yang sama yaitu Yayasan Pendidikan Cengkareng.

\section{Penutup}

\section{Kesimpulan}

Berdasarkan kajian yang dilakukan, setidaknya penulis dapat menyimpulkan bahwa pembelajaran sejarah merupakan pembelajaran atau pendidikan yang berkaitan dengan peristiswa masa lampau. Kegiatan di dalamnya adalah internalisasi nilai-nilai pengetahuan dan keterampilan yang berkaitan dengan sejarah. Dalam penelitian ini, materi sejarah yang menjadi perhatian penelitian adalah pembahasan mengenai "Perkembangan Hindu-Budha di Indonesia", yang meliputi sub-materi: (1) TeoriTeori Masuknya Agama dan Kebudayaan Hindu dan Buddha di Indonesia, dan (2) Pengaruh Hindu Buddha di Indonesia. Sebagai segala sesuatu yang dapat dimanfaatkan oleh siswa untuk mempelajari bahan sesuai dengan tujuan yang hendak dicapai, sumber sejarah merupakan aspek yang penting dalam pembelajaran sejarah.

17 Muhammad Sadikin, "Analisis Pembelajaran Sejarah dengan Pendekatan Saintifik pada Kurikulum 2013”, SOSIAL HORIZON: Jurnal Pendidikan Sosial, Vol. 4., No. 2, (Desember 2017), hal. 226. 
Sumber pembelajaran sejarah yang merupakan sarana pembelajaran dan pengajaran yang memiliki kaitan dengan ilmu sejarah adalah acuan pelaksanaan di dalam kegiatan belajar dan mengajar yang dilakukan.

Berdasarkan pengamatan dan wawancara yang dilakukan, dapat diketahui bahwa sumber belajar yang digunakan di SMK tergolong masih kurang karena sumbernya cenderung hanya buku paket saja. Penggunaan itu berdampak kepada sejumlah hal, antara lain: (a) Pembelajaran Sejarah; (b) Metode Pembelajaran; (c) Media yang Digunakan pada Pembelajaran Sejarah; (d) Pemberian Tugas dalam Pembelajaran; dan (e) Kendala yang Dihadapi. Dengan segala keterbatasan tersebut, selanjutnya pembelajaran sejarah dalam materi Perkembangan Hindu-Budha di Indonesia di lingkungan SMK menjadi tidak berjalan dengan optimal. Penyebab utama dari kegiatan pembelajaran yang belum efektif ini adalah penggunaan sumber sejarah yang masih monoton dan belum berkembang ke hal-hal lain yang kreatif.

\section{Saran}

Sebagaimana disebutkan sebelumnya, penelitian yang dilakukan di sejumlah sekolah menengah kejuruan yang ada di Jakarta ini menemukan bahwa penggunaan sumber sejarah yang ada di lingkungan sekolah belum optimal. Hal itu disebabkan oleh pelbagai macam faktor, mulai dari pribadi guru pengampu mata pelajaran sendiri, pihak sekolah, konsorsium mata pelajaran, hingga ke dinas-dinas terkait yang memang memiliki tanggung jawab terhadap aspek pendidikan di Indonesia.

Berdasarkan penelitian ini, penulis memiliki saran yang antara lain:

a) Untuk guru mata pelajaran, agar dapat bersikap profesional dengan cara menjalankan tugasnya dengan baik dan terus mengembangkan dirinya agar penguasaan dan penyampaian materi dapat dilakukan dengan cara yang lebih kreatif dan inovatif;

b) Untuk pihak sekolah, agar bisa memberikan keleluasaan dalam penghimpunan sumber dan pengolahannya untuk dibuat sebagai materi pembelajaran;

c) Untuk konsorsium mata pelajaran, diharapkan dapat memberikan bantuan dan supervisi terhadap kegiatan pembelajaran yang dilakukan oleh para guru mata pelajaran sejarah; 
d) Untuk dinas pendidikan, harapannya bisa mendorong guru sejarah agar terus bisa meningkatkan skill dan kemampuannya dengan cara memberikan bantuan terhadap pengembangan diri masing-masing guru.

\section{Ucapan Terima Kasih}

Pada kesempatan ini peneliti mengucapkan terima kasih yang tak terhingga kepada pihak-pihak yang telah membantu, baik secara fisik maupun non fisik. Terutama kepad dosen pembimbing saya ibu Murni dan Ibu Umasih serta kepada seluruh civitas akademika Universitas Negeri Jakarta yang telah membantu memfasilitasi penelitian ini.

\section{Daftar Pustaka}

Gagne, R.M. \& Briggs, L.J. 1979. Principle of Instructional Design (2nd ed.). New Yorks: Holt, Rinehart, and Winston.

Gunarya, Arlina. 2011. "Model Perilaku Belajar”, dalam TOT Basic Study Skills, (Agustus).

Merdiana, Arie Dwita, Atmaja, Hamdan Tri, dan Suryadi, Andy. 2017. "Pecinan Semarang Sebagai Sumber Belajar Sejarah Pokok Bahasan Kolonialisme Kelas XI IPS Di SMA Nasional Nusaputera Semarang Tahun Pelajaran 2016/2017”, Indonesian Journal of History Education, Vol .5, No. 1.

Prananda, Mohammad Namiraz, Sarkadi, dan Ibrahim, Nurzengky. 2018. "Efektivitas Sumber Pembelajaran Sejarah,” Jurnal Pendidikan Sejarah, Vol. 7, No. 2 (Juli).

Sadikin, Muhammad. 2017. "Analisis Pembelajaran Sejarah dengan Pendekatan Saintifik pada Kurikulum 2013”, SOSIAL HORIZON: Jurnal Pendidikan Sosial, Vol. 4., No. 2, (Desember).

Sanjaya, W. 2006. Strategi Pembelajaran: Berorientasi Standar Proses Pendidikan. Jakarta: Kencana Prenada Media Group.

Soebijantoro, Trisna Sri Wardani. 2017. “Upacara Adat Mantu Kucing di Desa Purworejo Kabupaten Pacitan (Makna Simbolis dan Potensinya Sebagai Sumber Pembelajaran Sejarah)", Jurnal Agastya, Vol. 7, No. 1 (Januari, 2017).

Subakti, Y.R. 2010. "Paradigma Pembelajaran Sejarah Berbasis Konstruktivisme". Jurnal SPPS. Vol. 24, No. 1, (April 2010).

Sudjana, Nana \& Rifai, Ahmad. 2003. Sumber Belajar dan Alat Pelajaran. Jakarta: Bumi Aksara.

Sudjana, Nana \& Rifai, Ahmad. 2007. Teknologi Pengajaran. Bandung: Sinar Baru Algensindo.

Suratno. 2008. Macam-Macam Sumber Belajar. Jakarta: Gramedia Pustaka Utama. 
Suryani, Nunuk dan Agung, Leo. 2012. Strategi Belajar Mengajar. Yogyakarta: Ombak.

Sutikno, M. Sobry. 2009. Belajar dan Pembelajaran: Upaya Kreatif dalam Mewujudkan Pembelajaran yang Berhasil. Bandung: Prospect.

Yamin, Martinis. 2013. Strategi dan Metode dalam Model Inovasi Pembelajaran. Jakarta: Gaung Persada Press Group.

Widja, I Gede. 1989. Dasar-Dasar Pengembangan Strategi Serta Metode Pengajaran Sejarah. Jakarta: Proyek Pengembangan Lembaga Pendidikan Tenaga Kependidikan.

Wineburg, Sam. 2001. Historical Thinking and Other Unnatural Acts: Charting the Future of Teaching the Past. Temple University Press. 